\title{
Analisis Statistik Konsumsi Energi Listrik Pada Bangunan Gedung Yayasan Widya Dharma Pontianak
}

\author{
Paskalia Kartini \\ Magister Teknik Elektro UniversitasTanjungpura Pontianak, \\ Staf Pengajar Sekolah Tinggi Manajemen Informatika dan Komputer Widya Dharma \\ e-mail : paskalia_k@yahoo.com
}

\begin{abstract}
Sektor utama yang menggunakan energi listrik terbesar di suatu negara adalah sektor industri, sektor transportasi, sektor rumah tangga, sektor komersial dan lain-lain. Bangunan/gedung merupakan subsektor dari sektor komersial sehingga perlu adanya suatu usaha konservasi energi listrik dalam rangka mengefisienkan konsumsi energi listrik dengan cara melihat peluang hemat energi. Penelitian ini dilaksanakan pada bangunan gedung Yayasan Widya Dharma Pontianak, yaitu dengan melakukan audit energi mengenai tingkat konsumsi energi listrik yang dilihat dari tingkat parameter Intensitas Konsumsi Energi (IKE). Dari hasil penelitian dan analisis statistik dengan ANOVA diketahui bahwa nilai IKE gedung A 87,49 $\mathrm{kWh} / \mathrm{m}^{2} /$ Tahun, gedung B 50,82 $\mathrm{kWh} / \mathrm{m}^{2} /$ Tahun serta gedung C $36 \mathrm{kWh} / \mathrm{m}^{2} /$ Tahun dan nilai IKE tersebut masih signifikan serta berada dalam kategori efisien sesuai dengan standar ESDM\&JICA Electric Power Development Co.,LTD bahwa IKE gedung komersial adalah 198,2 kWh/m ${ }^{2} /$ Tahun. Peluang Hemat Energi masih dapat dilakukan dengan mengganti AC lama dengan $A C$ inverter dengan nilai Net $B / C$ ratio 1,12 dan IRR $60,41 \%$.
\end{abstract}

Keywords- Konservasi Energi Listrik, IKE, Konservasi EnergiListrik, IKE UjiSignifikansi, AnalisisEkonomis

\section{Pendahuluan}

Kebutuhan energi listrik akan semakin meningkat mengikuti perkembangan dan pertumbuhan ekonomi, sedangkan hal tersebut tidak diimbangi oleh suplai energi listrik yang cukup. Menurut Data Outlook Energi Indonesia 2013 disebutkan bahwa pertumbuhan kebutuhan akan energi pada tahun 2011 - 2030 diperkirakan sebesar 4,7\% pertahun naik, dari sebelumnya yang rata-rata sebesar 3\% pertahun [1].

Ada lima sektor utama yang menjadi pengkonsumsi energi listrik terbesar di suatu negara yaitu sektor transportasi, sektor rumah tangga, sektor industri, sektor komersial dan lain-lain. Bangunan/gedung merupakan subsektor dari sektor komersial [2].

Untuk mengetahui besarnya konsumsi energi listrik pada sektor bangunan gedung digunakan parameter indikator efisiensi energi dengan menggunakan nilai Intensitas Konsumsi Energi (IKE).

Agar tidak terjadi pemborosan konsumsi energi listrik, Departemen Pertambangan dan Energi, membuat petunjuk teknis konservasi energi pada bangunan gedung pengkonsumsi energi yang cukup besar misalnya swalayan, rumah sakit, gedung perkantoran/pendidikan dan lain-lain.

Audit energi pada bangunan gedung dilakukan untuk mengetahui pola kebutuhan konsumsi energi pada bangunan gedung dan dilakukan analisis lebih lanjut (analisis statistik) serta untuk mendapatkan peluang hemat energi (PHE) pada bangunan gedung tersebut sehingga konsumsi energi listrik pada bangunan tersebut bisa lebih efisien dan menghemat biaya.

Pada penelitian ini akan dilaksanakan audit energi awal di bangunan gedung Yayasan Widya Dharma Pontianak yang terdiri dari dari 3 gedung (gedung $\mathrm{A}$, gedung B dan gedung C) di Jalan H.O.S. Cokroaminoto, Pontianak. Audit energi ini hanya dilakukan pada pencahayaan (lampu) dan alat pendingin (AC) pada gedung tersebut.

empat Pelaksanaan penelitian dilakukan di Bangunan Gedung Yayasan Widya Dharma. Ada tiga gedung yang dijadikan objek yaitu gedung $\mathrm{A}$, gedung $\mathrm{B}$ dan gedung C. Beban yang terpasang pada masing-masing adalah gedung A 82,5 kVA, gedung B 41,5 kVA, dan gedung C $66 \mathrm{kVA}$. Sumber data berasal dari PT.PLN berupa pemakaian daya listrik per-bulan selama dua tahun, beban harian yang dicatat per-jam selama satu minggu. Untuk data fisik bangunan didapat dari bagian umum / pengelola gedung yang diperlihatkan pada Tabel 1 untuk gedung A, Tabel 2 untuk gedung B dan Tabel 3 untuk gedung $\mathrm{C}$.

Tabel 1. Data Luas Bangunan Gedung A

\begin{tabular}{|l|c|c|c|}
\hline \multicolumn{1}{|c|}{ LANTAI } & $\begin{array}{c}\text { ROOM } \\
\left(\mathrm{m}^{2}\right)\end{array}$ & $\begin{array}{c}\text { NON ROOM } \\
\left(\mathrm{m}^{2}\right)\end{array}$ & $\begin{array}{c}\text { TOTAL } \\
\left(\mathrm{m}^{2}\right)\end{array}$ \\
\hline Lantai 1 (Basement) & - & 512 & 512 \\
Lantai 2 (Bagian Keuangan) & 384 & 40,8 & 424,8 \\
Lantai 3 (Ruang Kelas) & 384 & 40,8 & 424,8 \\
Lantai 4 (Ruang Kelas) & 384 & 40,8 & 424,8 \\
Lantai 5 (Perpustakaan) & 384 & 54,4 & 443,2 \\
Lantai 6 (Aula) & 448 & - & 448 \\
Toilet & 64 & - & 64 \\
\hline
\end{tabular}

Tabel 2. Data Luas Bangunan Gedung B

\begin{tabular}{|l|c|c|c|}
\hline \multicolumn{1}{|c|}{ LANTAI } & $\begin{array}{c}\text { ROOM } \\
\left(\mathrm{m}^{2}\right)\end{array}$ & $\begin{array}{c}\text { NON ROOM } \\
\left(\mathrm{m}^{2}\right)\end{array}$ & $\begin{array}{c}\text { TOTAL } \\
\left(\mathrm{m}^{2}\right)\end{array}$ \\
\hline Lantai 1 (Basement) & - & 217,6 & 217,6 \\
Lantai 2 (Bagian Umum) & 153,6 & 83,2 & 236,8 \\
Lantai 3 (Ruang Pimpinan) & 153,6 & 83,2 & 236,8 \\
Lantai 4 (Ruang Kelas) & 156,16 & 41,92 & 198,08 \\
Lantai 5 (Ruang Kelas) & 190,08 & 41,92 & 232 \\
Toilet & 40,32 & - & 40,32 \\
\hline
\end{tabular}


Tabel 3. Data Luas Bangunan Gedung C

\begin{tabular}{|l|c|c|c|}
\hline \multicolumn{1}{|c|}{ LANTAI } & $\begin{array}{c}\text { ROOM } \\
\left(\mathrm{m}^{2}\right)\end{array}$ & $\begin{array}{c}\text { NON ROOM } \\
\left(\mathrm{m}^{2}\right)\end{array}$ & $\begin{array}{c}\text { TOTAL } \\
\left(\mathrm{m}^{2}\right)\end{array}$ \\
\hline Lantai 1 (Cyber) & 232,96 & - & 232,96 \\
Lantai 2 (Sekretariat) & 224 & - & 224 \\
Lantai 3 (Ruang Kelas) & 181,44 & 47,36 & 228,8 \\
Lantai 4 (Ruang Kelas) & 181,44 & 47,36 & 228,8 \\
Toilet & 32 & - & 32 \\
\hline
\end{tabular}

Diagram alir penelitian yang akan dilakukan adalah sebagai berikut:

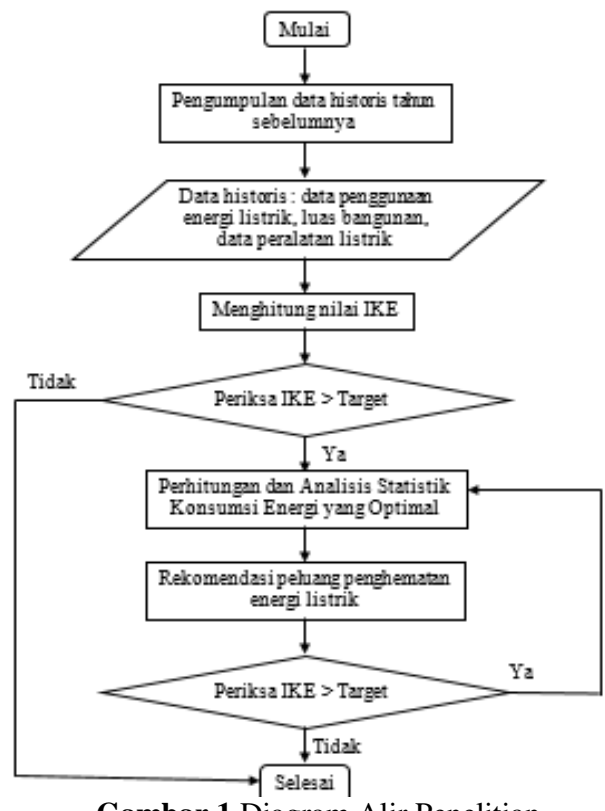

Gambar 1.Diagram Alir Penelitian

\section{LANDASAN TEORI}

Energi listrik merupakan suatu bentuk energi yang dinyatakan dalam Watt Hour. Energi yang digunakan oleh peralatan listrik secara matematis ditulis menjadi:

Energi = Daya $\mathrm{x}$ Waktu

dimana :

Energi = energi listrik yang dikonsumsi peralatan listrik (Watt Hour)

Daya = daya peralatan listrik (Watt)

Waktu = waktu selama peralatan digunakan (Hour)

Tarif dasar listrik (TDL) merupakan tarif yang dikenakan kepada konsumen yang menggunakan energi listrik yang bersumber dari PT.Perusahaan Listrik Negara (PLN). Berdasarkan Peraturan Menteri Energi dan Sumber Daya Mineral Republik Indonesia Nomor 09 Tahun 2014, tarif tenaga listrik ditetapkan berdasarkan golongan tarif, sebagai berikut:

1. Untuk keperluan pelayanan sosial (S)

2. Untuk keperluan rumah tangga $(\mathrm{R})$

3. Untuk keperluan bisnis (B)

4. Untuk keperluan industri (I)

5. Untuk keperluan kantor pemerintah dan penerangan jalan umum.

6. Untuk keperluan traksi pada tegangan menengah, dengan daya diatas $200 \mathrm{kVA}$ (T/TM) diperuntukkan bagi perusahaan perseroan (Persero) PT. Kereta Api Indonesia.[3]
Daya listrik menurut Goris Seran Daton (2007) adalah jumlah energi listrik yang digunakan tiap satuan waktu dalam detik dan dinyatakan dalam satuan Watt. Secara matematis ditulis sebagai:[4]

$$
\mathrm{P}=\mathrm{V} \times \mathrm{I}
$$

dimana :

$$
\begin{array}{ll}
\mathrm{P} & =\text { daya listrik (Watt) } \\
\mathrm{V} & =\text { tegangan (Volt) } \\
\mathrm{I} & =\text { aruslistrik (Ampere) }
\end{array}
$$

Daya sebenarnya yang dikonsumsi oleh peralatan listrik adalah:

dimana :

$$
\mathrm{P}=\mathrm{V}_{r m s} \times \mathrm{I}_{r m s} \times \cos \varphi
$$

$$
\begin{array}{ll}
\mathrm{P} & =\text { daya nyata/daya aktif (Watt) } \\
\mathrm{V}_{r m s} & =\text { tegangan (Volt) } \\
\mathrm{I}_{r m s} & =\text { arus listrik (Ampere) } \\
\varphi & =\text { sudut yang dibentuk oleh arus dan tegangan }
\end{array}
$$

Pada bangunan gedung, sistem konsumsi energi dapat dikelompokkan pada empat konsumsi energi listrik terbesar yaitu, AC, pencahayaan, transportasi gedung dan peralatan kantor lainnya.Persentase penggunaan energi listrik pada gedung komersial ditunjukkan pada Tabel 4.[5].

\begin{tabular}{cc} 
Tabel 4.Persentase Penggunaan & Energi di Gedung \\
\hline Penggunaan Energi & Persentase \\
\hline Sistem AC & $60 \%$ \\
Sistem pencahayaan & $20 \%$ \\
Sistem transportasi & $10 \%$ \\
Alat-alat lain & $10 \%$ \\
\hline
\end{tabular}

Audit energi merupakan aktivitas pemeriksaan berkala untuk mengetahui ada tidaknya penyimpangan dalam suatu kegiatan penggunaan energi, menentukan langkah perbaikannya serta mengevaluasi tingkat kelayakannya. Monitoring konsumsi energi secara teratur merupakan keharusan untuk mengetahui besarnya energi yang digunakan pada setiap bagian selama selang waktu tertentu sehingga usaha konservasi energi dapat dilakukan.

Berdasarkan ruang lingkup audit energi yang dilakukan maka dapat dibedakan menjadi dua jenis, yaitu audit energi awal dan audit energi rinci. Audit energi awal berupa pengumpulan data gedung dan tidak memerlukan pengukuran dalam pengumpulan datanya, data yang diperlukan yaitu data jenis bangunan dan ukuran ruangan, data rekening listrik. Dari data awal dapat dihitung:

1. Rincian luas bangunan $\left(\mathrm{m}^{2}\right)$.

2. Konsumsi energi listrik bulanan (kWh/bulan).

3. Intensitas Konsumsi Energi (IKE) bangunan gedung $\left(\mathrm{kWh} / \mathrm{m}^{2}\right)$.

4. Biaya energi listrik (Rp/kWh).

Audit energi rinci dilakukan jika nilai IKE dari hasil audit energi awal lebih besar dari nilai standar yang telah ditetapkan, dengan cara:

1. Membandingkan nilai IKE awal dengan IKE target.

2. Mengidentifikasi peluang konservasi energi yang 
bisa dilakukan.

IKE adalah pembagian antara konsumsi energi listrik dengan setiap satuan luas bangunan gedung pada kurun waktu tertentu (pertahun atau perbulan). Rumus untuk menghitung IKE pertahun adalah:[6].

$$
\mathrm{IKE}=\frac{\text { Energi yang digunakan }(\mathrm{kWh} / \mathrm{tahun})}{\text { luas bangunan }\left(\mathrm{m}^{2}\right)}
$$

Perhitungan nilai IKE bulanan dengan rumus:

$$
\mathrm{IKE}=\frac{\text { Energi yang digunakan }(\mathrm{kWh} / \mathrm{bulan})}{\text { luas bangunan }\left(\mathrm{m}^{2}\right)}
$$

Nilai IKE yang dipergunakan sebagai acuan pada masing-masing jenis bangunan gedung, bersifat dinamis dan dapat berubah berdasarkan hasil penelitian terbaru mengikuti perkembangan teknologi peralatan hemat energi dan tingkat kesadaran hemat energi pengguna bangunan gedung. Tabel 5. Memperlihatkan nilai IKE standar pada bangunan gedung dari berbagai sumber.

Tabel 5. IKE Listrik Hasil Penelitian ASEAN-USAID [7]

\begin{tabular}{lcc}
\hline \multicolumn{1}{c}{ Sumber } & $\begin{array}{c}\text { IKE } \\
\left(\mathrm{KWH} / \mathrm{m}^{2} / \text { tahun }\right)\end{array}$ & $\begin{array}{c}\text { Tahun } \\
\text { Pengeluaran } \\
\text { Standar }\end{array}$ \\
\hline ASEAN-USAID & 240 & 1987 \\
$\begin{array}{l}\text { ESDM\&JICA Electric Power Development } \\
\text { Co..LTD }\end{array}$ & 198,2 & 2008 \\
$\begin{array}{l}\text { Berdasarkan GBCI (Konsul Bangunan Hijau } \\
\text { Indonesia) }\end{array}$ & 250 & 2010 \\
$\begin{array}{l}\text { Peraturan Gubernur DKI Jakarta No.38 } \\
\text { tahun 2012 tentang Bangunan Gedung Hijau }\end{array}$ & $210-285$ & - \\
\hline
\end{tabular}

Nilai IKE dapat dijadikan standar mengenai konsumsi energi listrik pada bangunan seperti diperlihatkan pada Tabel 6.[8]

\begin{tabular}{|c|c|c|}
\hline \multirow[t]{2}{*}{ Kriteria } & \multicolumn{2}{|c|}{$\begin{array}{l}\text { Konsumsi Energi Listrik } \\
\text { Bulanan }(\mathrm{kWh} / \mathrm{m} 2 / \mathrm{bln})\end{array}$} \\
\hline & Ber-AC & Tidak Ber-AC \\
\hline Sangat Efisien & $4,71-7,92$ & \\
\hline Efisien & $7,92-12,08$ & $0,84-1,67$ \\
\hline Cukup Efisien & $12,08-14,58$ & $1,67-2,5$ \\
\hline Agak Boros & $15,58-19,17$ & \\
\hline Boros & $19,17-23,75$ & $2,5-3,34$ \\
\hline Sangat Boros & $23,75-37,5$ & $3,34-4,17$ \\
\hline
\end{tabular}

Tabel 6. Kriteria Nilai IKE Pada Konsumsi Energi Listrik

Korelasi merupakan teknik statistik yang digunakan untuk menguji ada tidaknya hubungan antara dua atau lebih variabel, juga untuk melihat arah hubungan bersifat positif (berbanding lurus) atau negatif (berbanding terbalik). Koefisien korelasi ganda dirumuskan sebagai :

$$
R_{x_{1} x_{2} y}=\sqrt{\frac{\left(r_{x_{1} y}\right)^{2}+\left(r_{x_{2} y}\right)^{2}-2 \cdot r_{x_{1} y} \cdot r_{x_{2} y} \cdot r_{x_{1} x_{2}}}{1-\left(r_{x_{1} x_{2}}\right)^{2}}}
$$

dimana :

$\mathrm{R}_{\mathrm{x}_{1} \mathrm{x}_{2} \mathrm{y}}=$ korelasi antara variabel $x_{1}$ dan $x_{2}$ pada $\mathrm{y}$

$r_{x_{1} y}=$ korelasi antara variabel $x_{1}$ terhadap $\mathrm{y}$

$r_{x_{2} y}=$ korelasi antara variabel $x_{2}$ terhadap $\mathrm{y}$ $r_{x_{1} x_{2}}=$ korelasi antara variabel $x_{1}$ terhadap $x_{2}$

Hubungan antara koefisien korelasi (R) diperlihatkan dalam Tabel.7

Tabel 7. Tingkat Hubungan Koefisien Korelasi

\begin{tabular}{cc}
\hline Interval Koefisien & Tingkat Hubungan \\
\hline $0,00-0,1999$ & Sangat rendah \\
$0,20-0,3999$ & Rendah \\
$0,40-0,5999$ & Cukup \\
$0,60-0,7999$ & Kuat \\
$0,80-1,000$ & Sangat kuat \\
\hline
\end{tabular}

Untuk pengujian signifikan koefisien korelasi ganda dengan menggunakan rumus:[9]

$$
\mathrm{F}_{\text {hitung }}=\frac{\mathrm{R}^{2} / \mathrm{k}}{\left(1-\mathrm{R}^{2}\right) /(\mathrm{n}-\mathrm{k}-1)}
$$

dimana :

$\mathrm{F}_{\text {hitung }}=$ tingkat signifikansi korelasi ganda

$\mathrm{R} \quad=$ koefisien korelasi ganda

$\mathrm{k} \quad=$ jumlah variabel independen

$\mathrm{n} \quad=$ jumlah sampel

\section{HASIL DAN PEMBAHASAN}

Penelitian tentang analisis konsumsi energi listrik pelaksanaannya di gedung Yayasan Widya Dharma Pontianak. Pengambilan data penelitian dilakukan pada tiga gedung bangunan yaitu gedung $\mathrm{A}$, gedung $\mathrm{B}$ dan gedung C. Rata-rata konsumsi energi listrik pada masing-masing gedung diperlihatkan pada Tabel 8 .

Tabel 8. Data Konsumsi Energi Listrik Per-Gedung

\begin{tabular}{ccc}
\hline GEDUNG & $\begin{array}{c}\text { TOTAL KONSUMSI } \\
\text { ENERGI LISTRIK }\end{array}$ & $\begin{array}{c}\text { RATA-RATA } \\
\text { KONSUMSI PER- } \\
\text { BULAN }\end{array}$ \\
\hline Gedung A & $408634 \mathrm{KWH}$ & $15134,59 \mathrm{KWH}$ \\
Gedung B & $91929 \mathrm{KWH}$ & $3404,78 \mathrm{KWH}$ \\
Gedung C & $75980 \mathrm{KWH}$ & $2814,074 \mathrm{KWH}$ \\
\hline
\end{tabular}

Untuk perbandingan konsumsi energi listrik antar gedung diperlihatkan dalam Gambar 2.

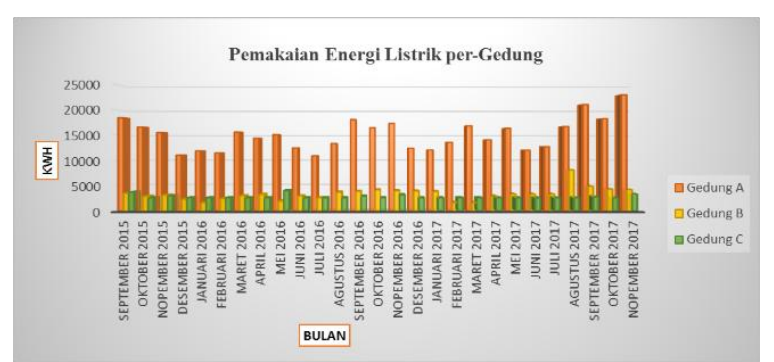

Gambar 2. Perbandingan konsumsi energi listrik

Dari Gambar 2. memperlihatkan bahwa gedung A mempunyai tingkat konsumsi energi listrik yang terbesar dibandingkan dengan gedung $\mathrm{B}$ dan $\mathrm{C}$, sedangkan konsumsi energi listrik pada gedung $\mathrm{B}$ dan $\mathrm{C}$ relatif hampir sama. Hal ini terjadi karena pada gedung $\mathrm{A}$ terdapat Lift Elevator yang mengkonsumsi energi listrik yang besar. Untuk perbandingan konsumsi energi listrik selanjutnya pada ketiga gedung hanya dibatasi pada konsumsi Lampu dan AC (Air Conditioner). 
Analisis data kebutuhan energi listrik pada bangunan gedung A pada Tabel 9., gedung B pada Tabel 10 dan gedung $\mathrm{C}$ pada Tabel 11.

Tabel.9 Total Kebutuhan Energi Listrik per-hari di Gedung A

\begin{tabular}{|c|c|c|c|c|c|c|c|c|}
\hline Lantai & $\begin{array}{l}\text { Jumbiah } \\
\text { Lampou } \\
\text { (ety) }\end{array}$ & $\begin{array}{l}\text { Lama } \\
\text { opeasi } \\
\text { opear) }\end{array}$ & $\begin{array}{l}\text { Tota1 } \\
\text { Daya } \\
\text { Lampu }\end{array}$ & $\begin{array}{c}\text { Jumbah } \\
\text { AC } \\
\text { (Qty) }\end{array}$ & $\begin{array}{l}\text { Lama } \\
\text { opeasi } \\
\text { (Howr) }\end{array}$ & $\begin{array}{l}\text { Tota1 } \\
\text { Daya } \\
\text { AC }\end{array}$ & $\begin{array}{l}\text { Total } \\
\text { Daya } \\
\text { (KWh) }\end{array}$ & $\begin{array}{c}\text { Luas } \\
\text { Bangunan } \\
\left(\mathrm{m}^{2}\right)\end{array}$ \\
\hline 1 & & & & & & & 1,68 & \\
\hline 2 & 63 & 8 & 9.072 & $\mathbf{8}$ & 8 & 53.76 & 62.832 & 424.8 \\
\hline 3 & so & 13 & 18.720 & $\mathbf{8}$ & 13 & 87.36 & 106,08 & 424.8 \\
\hline 4 & 80 & 13 & 18.720 & 8 & 13 & 87.36 & 106.08 & 424.8 \\
\hline 5 & so & 14 & 20.160 & 8 & 14 & 94.08 & 114.24 & 443.2 \\
\hline 6 & 60 & 1 & 1,080 & 8 & 5 & 20 & 21,080 & 448 \\
\hline Total & 363 & 49 & 67.752 & 36 & 56 & 342,56 & 410,312 & 2165,6 \\
\hline
\end{tabular}

Tabel.10 Total Kebutuhan Energi Listrik per-hari di Gedung B

\begin{tabular}{|c|c|c|c|c|c|c|c|c|}
\hline Lantai & $\begin{array}{c}\text { Jumlah } \\
\text { Lampu } \\
\text { (Qty) }\end{array}$ & $\begin{array}{c}\text { Lama } \\
\text { Opeasi } \\
\text { (Hour) }\end{array}$ & $\begin{array}{c}\text { Total } \\
\text { Daya } \\
\text { Lampu }\end{array}$ & $\begin{array}{c}\text { Jumlah } \\
\text { AC } \\
\text { (Qty) }\end{array}$ & $\begin{array}{c}\text { Lama } \\
\text { Opeasi } \\
\text { (Hour) }\end{array}$ & $\begin{array}{c}\text { Total } \\
\text { Daya } \\
\text { AC }\end{array}$ & $\begin{array}{c}\text { Total } \\
\text { Daya } \\
\text { (KWh) }\end{array}$ & $\begin{array}{c}\text { Luas } \\
\text { Bangunan } \\
\left(\mathbf{m}^{2}\right)\end{array}$ \\
\hline 1 & 7 & 11 & 1,078 & - & - & - & 1,078 & 217,6 \\
2 & 51 & 6 & 5.508 & 8 & 7 & 47.04 & 52.548 & 236.8 \\
3 & 63 & 6 & 6,804 & 9 & 8 & 60.48 & 67.284 & 236,8 \\
4 & 42 & 5 & 3.780 & 6 & 5 & 25,20 & 28,98 & 198,08 \\
5 & 36 & 8 & 5,184 & 6 & 5 & 25,20 & 30,384 & 232 \\
\hline Total & 192 & 25 & 22,276 & 29 & 25 & 157,92 & 179,196 & 903,68 \\
\hline
\end{tabular}

Tabel.11 Total Kebutuhan Energi Listrik per-hari di Gedung C

\begin{tabular}{|c|c|c|c|c|c|c|c|c|}
\hline Lantai & $\begin{array}{c}\text { Jumlah } \\
\text { Lampu } \\
\text { (Qty) }\end{array}$ & $\begin{array}{l}\text { Lama } \\
\text { Opeasi } \\
\text { (Hour) }\end{array}$ & $\begin{array}{c}\text { Total } \\
\text { Daya } \\
\text { Lampu }\end{array}$ & $\begin{array}{c}\text { Jumlah } \\
\text { AC } \\
\text { (Qty) }\end{array}$ & $\begin{array}{l}\text { Lama } \\
\text { Opeasi } \\
\text { (Hour) }\end{array}$ & $\begin{array}{c}\text { Total } \\
\text { Daya } \\
\text { AC }\end{array}$ & $\begin{array}{l}\text { Total } \\
\text { Daya } \\
(\mathrm{KWh})\end{array}$ & $\begin{array}{c}\text { Luas } \\
\text { Bangunan } \\
\left(\mathrm{m}^{2}\right)\end{array}$ \\
\hline 1 & 21 & 10 & 2,94 & 7 & 10 & 42 & 44,94 & 232,96 \\
\hline 2 & 36 & 5 & 3,24 & 7 & 7 & 41,16 & 44,4 & 224 \\
\hline 3 & 69 & 5 & 6,21 & 6 & 5 & 25,2 & 31,41 & 228,8 \\
\hline 4 & 69 & 5 & 6,21 & 3 & 5 & 12,6 & 18,81 & 228,8 \\
\hline Total & 195 & 25 & 18,6 & 23 & 27 & 120,96 & 139,56 & 914,56 \\
\hline
\end{tabular}

secara rinci diperlihatkan dalam Gambar 3, Gambar 4 dan Gambar 5.

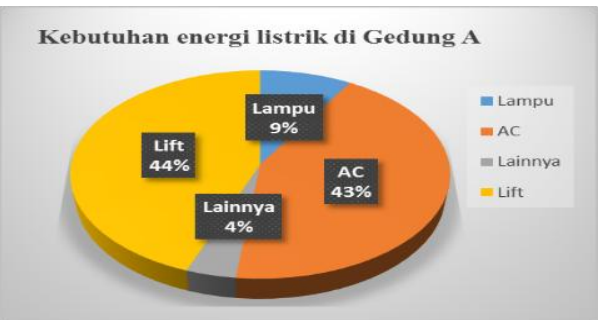

Gambar 3. Kebutuhan listrik harian gedung A
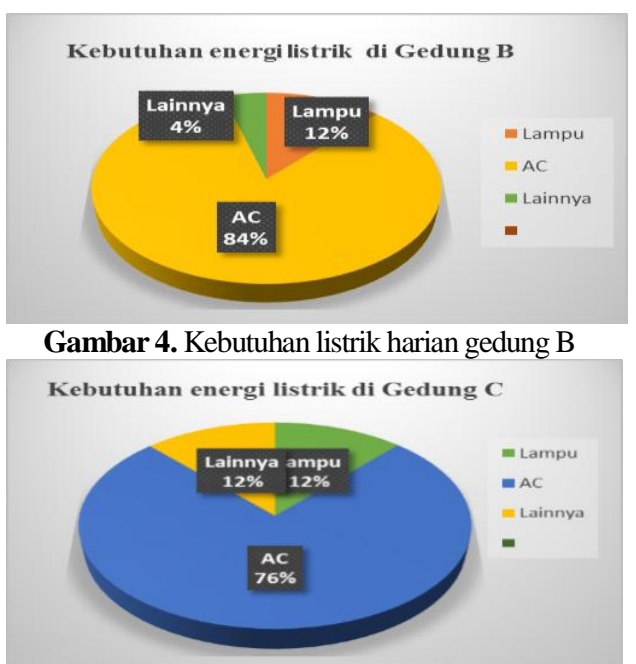

Gambar 5. Kebutuhan listrik harian gedung C
Berdasarkan Tabel 4. Tentang persentase penggunaan energi listrik pada bangunan gedung untuk komponen lampu sebesar 20\%. Dan untuk AC sebesar $60 \%$, maka Secara visual diperlihatkan perbandingan persentase konsumsi energi listrik untuk lampu pada Gambar 6 dan AC pada Gambar 7.

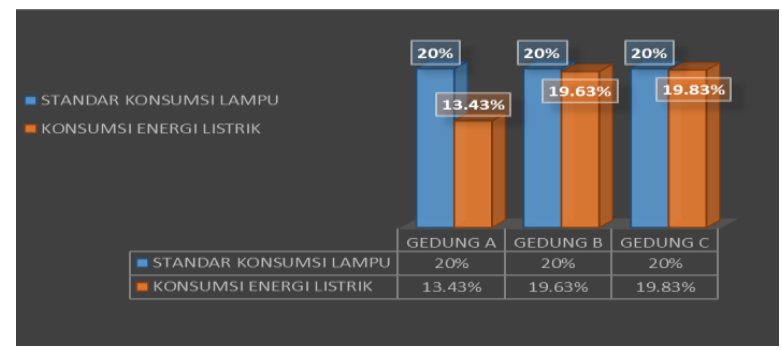

Gambar 6. Perbandingan konsumsi energi listrik pada lampu

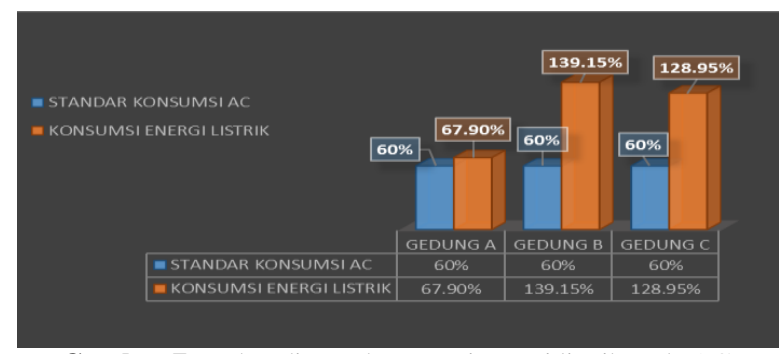

Gambar 7. Perbandingan konsumsi energi listrik pada AC

Penentuan nilai parameter IKE pada masing-masing gedung diperlihatkan pada Gambar 8 .

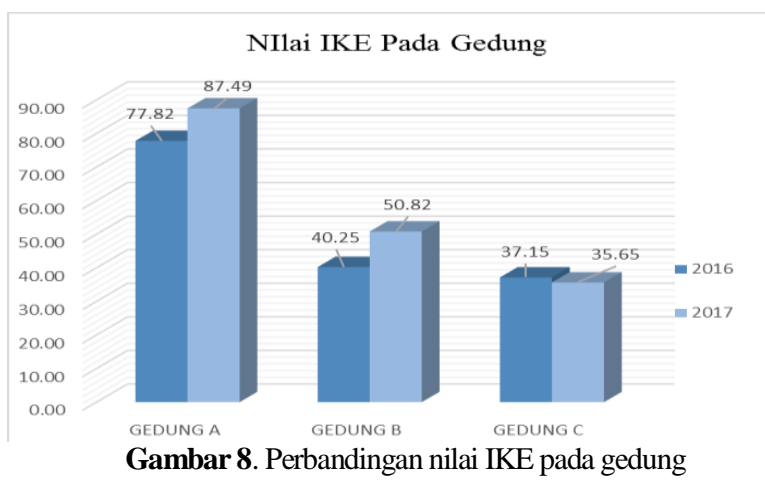

Dari Gambar 6 memperlihatkan bahwa nilai IKE gedung $\mathrm{A}$, gedung $\mathrm{B}$ dan gedung $\mathrm{C}$ berada jauh dibawah batas standar IKE ASEAN-USAID 1992, yaitu standar untuk kategori bangunan gedung perkantoran (komersial) sebesar $240 \mathrm{Kwh} / \mathrm{m}^{2} /$ tahun. Jika dilihat perbandingan nilai IKE dari tahun 2016 dan tahun 2017, terjadi trend peningkatan nilai IKE, meskipun masih dibawah standar yang ditetapkan.

\section{Uji ANOVA}

Pengujian nilai Intensitas Konsumsi Energi gedung Yayasan Widya Dharma ditinjau dari konsumsi energi listrik pada lampu/pencahayaan, pada Tabel 11. 
Tabel 11. Data IKE Bangunan Gedung

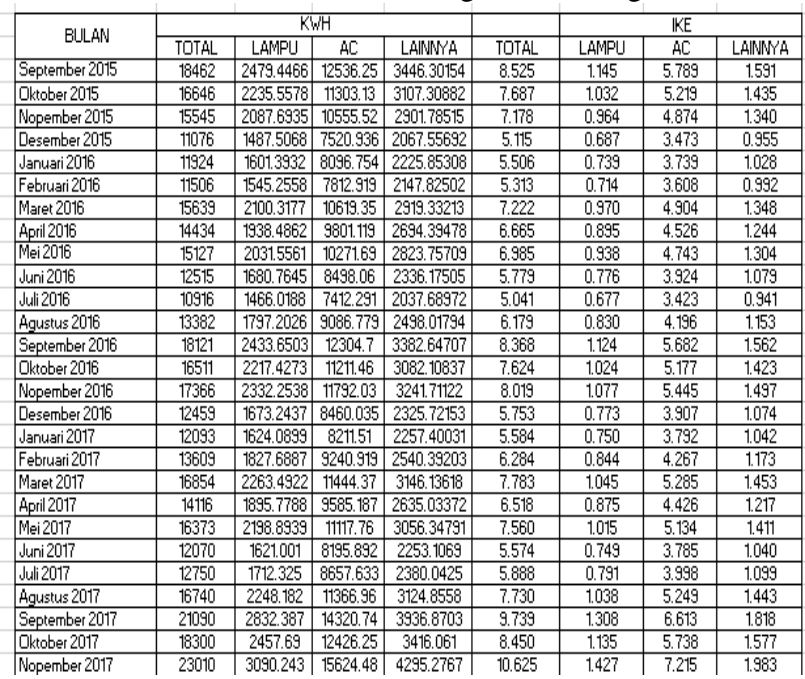

berdasarkan standar nilai IKE untuk bangunan gedung ber-AC, yaitu:

1. Hipotesis

" $\mathrm{H}_{\mathrm{o}}$ : "Intensitas Konsumsi Energi pada bangunan gedung $\mathrm{A}, \mathrm{B}$ dan $\mathrm{C}$ belum memenuhi standar nilai IKE yang telah ditetapkan

" $\mathrm{H}_{1}$ : "Intensitas Konsumsi Energi pada bangunan gedung $\mathrm{A}, \mathrm{B}$ dan $\mathrm{C}$ memenuhi standar nilai IKE yang telah ditetapkan"

2. $\alpha=0,05$

3. Kriteria uji

$\mathrm{H}_{\mathrm{o}}$ ditolakjika|f_hitung $>$ f-tabel atau $\rho$-value $<\alpha$

4. Rasio Uji menggunakan ANOVA

Tabel 12. Hasil Anova Pada Lampu

\begin{tabular}{|c|c|c|c|c|c|c|}
\hline \multicolumn{7}{|l|}{ Anova: Single Factor } \\
\hline \multicolumn{7}{|l|}{ SUMMARY } \\
\hline Groups & Count & Sum & Average & Variance & & \\
\hline GEDUNG A & 27 & 25.341497 & 0.938574 & 0.03656074 & & \\
\hline GEDUNG B & 27 & 19.96705 & 0.7395204 & 0.07757615 & & \\
\hline GEDUNG C & 27 & 16.473577 & 0.6101325 & 0.00641673 & & \\
\hline \multicolumn{7}{|l|}{ ANOVA } \\
\hline Source of Variation & SS & $d f$ & MS & $F$ & P-value & Fcrit \\
\hline LAMPU & 1.4781364 & 2 & 0.7390682 & 18.3918543 & $2.86 \mathrm{E}-07$ & 3.11379226 \\
\hline ERROR & 3.1343942 & 78 & 0.0401845 & & & \\
\hline Total & 4.6125306 & 80 & & & & \\
\hline
\end{tabular}

Pengambilan keputusan

a.Nilai f hitung $(18,3918543)>\mathrm{f}$ tabel $(3,11379226)$, maka $\mathrm{H}_{\mathrm{o}}$ ditolak

b.Nilai $\rho$-value $(0,000000286)<$ alpha $(0,05)$, maka $\mathrm{H}_{\mathrm{o}}$ ditolak.

Kesimpulannya adalah nilai Intensitas Konsumsi Energi pada bangunan gedung $\mathrm{A}, \mathrm{B}$ dan $\mathrm{C}$ jika ditinjau dari komponen lampu/pencahayaan memenuhi standar nilai IKE yang telah ditetapkan .

Pengujian nilai Intensitas Konsumsi Energi gedung Yayasan Widya Dharma ditinjau dari konsumsi energi listrik pada AC, berdasarkan standar nilai IKE untuk bangunan gedung ber-AC, yaitu:
1. Hipotesis

" $\mathrm{H}_{\mathrm{o}}$ : "Intensitas Konsumsi Energi pada bangunan gedung $\mathrm{A}, \mathrm{B}$ dan $\mathrm{C}$ belum memenuhi standar nilai IKE yang telah ditetapkan

" $\mathrm{H}_{1}$ : "Intensitas Konsumsi Energi pada bangunan gedung $\mathrm{A}, \mathrm{B}$ dan $\mathrm{C}$ memenuhi standar nilai IKE yang telah ditetapkan"

2. $\alpha=0,05$

3. Kriteria uji

$\mathrm{H}_{\mathrm{o}}$ ditolakjika|f_hitung $\mid>$ f-tabel atau $\rho$-value $<\alpha$

4. Rasio Uji menggunakan ANOVA

Tabel 13. Hasil Anova Pada AC

\begin{tabular}{|c|c|c|c|c|c|c|}
\hline \multicolumn{7}{|l|}{ Anova: Single Factor } \\
\hline \multicolumn{7}{|l|}{ SUMMARY } \\
\hline Groups & Count & Sum & Average & Variance & & \\
\hline GEDUNG A & 27 & 128.1283 & 4.745494 & 0.93463248 & & \\
\hline GEDUNG B & 27 & 141.5496 & 5.242577 & 3.898680044 & & \\
\hline GEDUNGC & 27 & 107.131 & 3.967815 & 0.271374045 & & \\
\hline \multicolumn{7}{|l|}{ ANOVA } \\
\hline Source of Variation & SS & $d f$ & MS & $F$ & P-value & Fcrit \\
\hline$A C$ & 22.29206 & 2 & 11.14603 & 6.550467949 & 0.002346 & 3.113792 \\
\hline ERROR & 132.7219 & 78 & 1.701562 & & & \\
\hline Total & 155.0139 & 80 & & & & \\
\hline
\end{tabular}

Pengambilankeputusan

a.Nilai f hitung $(6,550467949)>\mathrm{f}$ tabel $(3,11379226)$, maka $\mathrm{H}_{\mathrm{o}}$ ditolak

b.Nilai $\rho$-value $(0,002346)<$ alpha $(0,05)$, maka $\mathrm{H}_{\mathrm{o}}$ ditolak.

Kesimpulannya adalah nilai Intensitas Konsumsi Energi pada bangunan gedung $\mathrm{A}, \mathrm{B}$ dan $\mathrm{C}$ jika ditinjau dari komponen AC memenuhi standar nilai IKE yang telah ditetapkan .

Untuk menguji dan memperkirakan korelasi variabel bebas lampu $\left(\mathrm{X}_{1}\right)$ dan $\mathrm{AC}\left(\mathrm{X}_{2}\right)$ terhadap variabel terikat nilai IKE (Y) pada bangunan gedung. Langkahnya adalah sebagai berikut:

A. Membuat Persamaan Linear Ganda

1. Membuat tabel hitung data

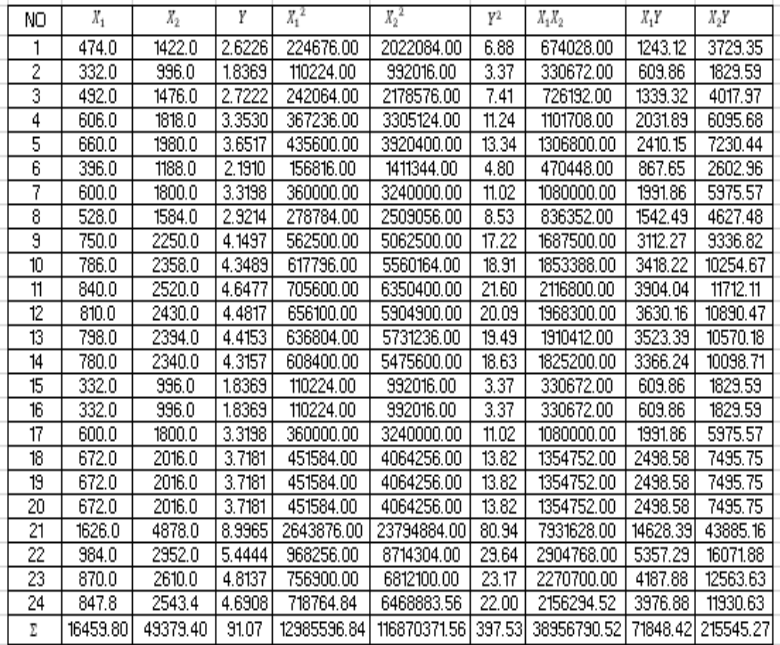


2. Menghitung nilai koefisien a dan $b$ menggunakan bentuk:

$$
\begin{gathered}
n a+\sum X_{1} b_{1}+\sum X_{2} b_{2}=\sum Y \\
\sum X_{1} a+\sum X_{1}{ }^{2} b_{1}+\sum X_{1} X_{2} b_{2}=\sum X_{1} Y \\
\sum X_{2} a+\sum X_{1} X_{2} b_{1}+\sum X_{2}{ }^{2} b_{2}=\sum X_{2} Y
\end{gathered}
$$

Didapatkan persamaan linear:

(i) $\quad 24 a+17,88 b_{1}+126,72 b_{2}=91,07$

(ii) $\quad 17,88 a+15,32 b_{1}+108,57 b_{2}=78,03$

(iii) $\quad 126,72 a+108,57 b_{1}+769,69 b_{2}=553,15$

3. Penyelesaian persamaaan linear dengan metode eliminasi dan subtitusi didapatkan hasil dan nilai :

$$
\begin{aligned}
& \quad a=-0,0803 \\
& b_{1}=0,00013 \quad b_{2}=0,00184
\end{aligned}
$$

4. Kesimpulan

Persamaan regresi linear ganda adalah :

$$
\begin{aligned}
& Y=a+b_{1} X_{1}+b_{2} X_{2} \\
& Y=-0,0803+0,00013 X_{1}+0,00184 X_{2}
\end{aligned}
$$

Dilihat dari persamaan regresi ganda, nilai absolut $b_{2}$ lebih besar dibandingkan dengan nilai absolut $b_{1}$, dimana $b_{2}$ menandakan kemiringan variabel $X_{2}$ (nilai IKE AC) dan $b_{1}$ menandakan kemiringan variabel $X_{1}$ (nilai IKE lampu), berarti dapat disimpulkan bahwa persentase nilai IKE konsumsi energi listrik pada AC lebih berpengaruh daripada nilai IKE konsumsi energi listrik pada lampu.

Uji Korelasi

1. Menentukan Hipotesis Pengujian

$\mathrm{H}_{0}$ : Tidak terdapat hubungan antara pemakaian energi listrik pada lampudan AC terhadap nilai IKE

$\mathrm{H}_{1}$ : Terdapat hubungan antara pemakaian energi listrik pada lampu danAC terhadap nilai IKE

2. Menentukan Statistik Uji menggunakan korelasi Ganda, didapat dari persamaan (7):

$$
\mathrm{F}_{\text {hitung }}=\frac{\mathrm{R}^{2} / \mathrm{k}}{\left(1-\mathrm{R}^{2}\right) /(\mathrm{n}-\mathrm{k}-1)}
$$

3. Taraf nyata $(\alpha)=0,05$

4. Kriteria Pengujian

Jika $\mathrm{F}_{\text {hitung }}>\mathrm{F}_{\text {tabel }}$ maka $\mathrm{H}_{0}$ ditolak, artinya signifikan

Jika $\mathrm{F}_{\text {hitung }}<\mathrm{F}_{\text {tabel }} \quad$ maka $\mathrm{H}_{0}$ diterima, artinya tidak signifikan

5. Nilai Statistik Uji

Jika $x_{1}=$ pemakaian energi listrik pada lampu perbulan

$x_{2}=$ pemakaian energi listrik pada $\mathrm{AC}$ per bulan $y=$ nilai IKE

Diketahui : jumlah data $(\mathrm{n})=24$,

variabel independen $=2$

Dengan menggunakan korelasi linear didapatkan nilai

$$
\begin{aligned}
& r_{x_{1} y}=1 \\
& r_{x_{1} y}=1 \\
& r_{x_{1} x_{2}}=366,685
\end{aligned}
$$

Dari persamaan (6) didapatkan:

$$
\begin{aligned}
& R_{x_{1} x_{2} y}=\sqrt{\frac{\left(x_{x_{1} y}\right)^{2}+\left(r_{x_{2} y}\right)^{2}-2 \cdot r_{x_{1} y} \cdot r_{x_{2} y} \cdot r_{x_{1} x_{2}}}{1-\left(r_{x_{1} x_{2}}\right)^{2}}} \\
& R_{x_{1} x_{2} y}=\sqrt{\frac{1^{2}+(1)^{2}-2 \cdot(1)(1) \cdot(366,685)}{1-(366,685)^{2}}}=0,07375
\end{aligned}
$$

Nilai korelasi ganda 0,07375 artinya hubungan antara variabel $\mathrm{x} 1$ dan $\mathrm{x} 2$ terhadap variabel $\mathrm{y}$ sangat rendah.

6. Nilai Statistik uji

$\mathrm{F}_{\text {hitung }}=\frac{\mathrm{R}^{2} / \mathrm{k}}{\left(1-\mathrm{R}^{2}\right) /(\mathrm{n}-\mathrm{k}-1)}=\frac{(0,07375)^{2} / 2}{\left(1-(0,07375)^{2}\right) /(24-2-1)}=0,057$

7. Menentukan nilai $F$ pada Tabel

$$
\mathrm{F}_{\text {tabel }}(2,21)=3,47
$$

\section{Kesimpulan}

Karena nilai $F_{\text {hitung }}(0,057)<\mathrm{F}_{\text {tabel }}(3,47)$ maka $\mathrm{H}_{\mathrm{o}}$ diterima, artinya Tidak terdapat hubungan yang signifikan antara pemakaian energi listrik pada lampu dan AC terhadap nilai IKE, terdapat faktor lainnya.

\section{Peluang Hemat Energi}

Meskipun nilai IKE pada ketiga gedung berada dlam kategori efisien yaitu berada diantara 35,65 sampai dengan $87,49 \mathrm{kWh} / \mathrm{m}^{2} /$ tahun, tetapi ada kecendrungan terjadi peningkatan dari tahun sebelumnya. Untuk itu dicarikan usaha untuk melakukan penghematan dengan cara mengganti $\mathrm{AC}$ yang terpasang dengan yang baru. Tabel 14 menunjukkan kondisi AC yang terpasang saat ini.

\begin{tabular}{cccccc}
\multicolumn{6}{c}{ Tabel 14. Kondisi AC Terpasang Saat Ini. } \\
\hline \multirow{2}{*}{ Ruang } & Jumlah & Output Capacity & Kebutuhan & Kongkumsi & Pembayaran \\
& Unit & (BTU/h) & (BTU/h) & Listrik & Listrik PLN \\
(kWh/tahun) & $(\mathrm{Rp})$ \\
\hline Kelas & 2 & $18.000 \mathrm{BTU}$ & $52.153 \mathrm{BTU}$ & $4.905,6$ & 4.415 .040 \\
Jumlah & \multirow{2}{*}{30} & $270.000 \mathrm{BTU}$ & $782.288 \mathrm{BTU}$ & 73.584 & 66.225 .600 \\
\hline
\end{tabular}

\section{A.Spesifikasi ruang kelas}

Ukuran ruangan $=$ Panjang $=10 \mathrm{~m}$, Lebar $=8 \mathrm{~m}$,

Tinggi $=3 \mathrm{~m}$

Volume ruangan $=240 \mathrm{~m}^{3}$

Luas Lantai $\quad=80 \mathrm{~m}^{2}$

Luas Dinding $\left(\mathrm{A}_{\text {dinding }}\right)=47 \mathrm{~m}^{2}$

Ukuran Jendela =Panjang $=3 \mathrm{~m}$, Lebar $=1 \mathrm{~m}$

Jumlah Jendela $\quad=2$

Luas Jendela $\left(\mathrm{A}_{\text {jendela }}\right) \quad=6 \mathrm{~m}^{2}$

Ukuran Pintu $=$ Panjang $=2 \mathrm{~m}$, Lebar $=2,5 \mathrm{~m}$

Luas Pintu $\left(\mathrm{A}_{\text {pintu }}\right) \quad=5 \mathrm{~m}^{2}$ 
Temperatur Udara Luar $\left(\mathrm{T}_{\mathrm{o}}\right) \quad=32^{0} \mathrm{C}$ Intensitas Radiasi Matahari $=695 \mathrm{~W} / \mathrm{m}^{2}$ Temperatur Udara Dalam $\left(\mathrm{T}_{1}\right)=25^{\circ} \mathrm{C}$ Perbedaan Temperatur $(\Delta \mathrm{T}) \quad=7^{0} \mathrm{C}$ Tebal Lapis Plester Luar $=0,015 \mathrm{~m}$ Tebal Lapis Plester Dalam $\quad=0,015 \mathrm{~m}$ Tebal Batu Bata $\quad=0,08 \mathrm{~m}$

\section{B. Menghitung Kapasitas AC yang dibutuhkan:}

$\mathrm{Q}_{\mathrm{i}}=\sum$ panas (panas manusia + peralatan elektonik)

$=$ (panas manusia+daya laptop+daya proyektor+daya lampu)

$=(40.150 \mathrm{Watt}+1.50 \mathrm{Watt}+1.170 \mathrm{Watt}+12.18 \mathrm{Watt})$ $=6436 \mathrm{Watt}$

$\mathrm{cp}=$ panas jenis udara,

$\mathrm{V}=$ ventilasi $=($ volume ruangan $)($ pergantian udara per jam ( 3600 detik)

$=(240)(4) \cdot / 3600=0,27 \mathrm{~m}^{3} / \operatorname{detik}$

$\mathrm{Q}_{\mathrm{v}}=\mathrm{cp} \cdot \mathrm{V} \cdot \Delta \mathrm{T}$

$Q_{v}=\left(1300 \mathrm{~J} / \mathrm{m}^{30} \mathrm{C}\right)\left(0,27 \mathrm{~m}^{3} / \operatorname{detik}\right) \cdot\left(9^{0} \mathrm{C}\right)=7488$ Watt

$\mathrm{Q}_{\mathrm{c}}=$ panas melalui dinding + panas melalui kaca

$\mathrm{Q}_{\mathrm{c}}=\mathrm{A}_{\text {dinding }} \cdot \mathrm{U}_{\text {dinding }} \cdot \Delta \mathrm{T}+\mathrm{A}_{\text {kaca }} \cdot \mathrm{U}_{\text {kaca }} \cdot \Delta \mathrm{T}$ $=\left(47 \mathrm{~m}^{2}\right)\left(3,344 \mathrm{~W} / \mathrm{m}^{20} \mathrm{C}\right)\left(7{ }^{0} \mathrm{C}\right)+\left(6 \mathrm{~m}^{2}\right)(6,2$

$\left.\mathrm{W} / \mathrm{m}^{20} \mathrm{C}\right)\left(7^{0} \mathrm{C}\right)$

$$
=1360,576 \text { Watt }
$$

Panas yang harus diambil oleh mesin penyejuk (AC) adalah:

$$
Q_{m}=Q_{i}+Q_{v}+Q_{c}
$$

$=6436 \mathrm{Watt}+7488 \mathrm{Watt}+1360,576 \mathrm{Watt}$

$=15284,576 \mathrm{Watt}=15,28 \mathrm{~kW}$

\section{Spesifikasi AC terpasang saat ini}

Split Room Air Conditioner terpasang tahun 2009

$\begin{array}{ll}\text { Panasonic Model } & \quad: \text { S-26PK } \\ \text { Capacity } & : 9000 \mathrm{BTU} / \mathrm{h} \\ \text { Input } & : 840 \mathrm{Watt} \\ \text { Phase } & : 1 \Phi \\ \text { Voltage } & : 220-240 \mathrm{Volt} \\ \text { Frequncy } & : 50 \mathrm{~Hz} \\ \text { Refrigeran } & : \mathrm{R}-410 \mathrm{~A} \\ \text { Tahun pemasangan } \quad: 2009\end{array}$

Perbandingan AC yang terpasang diperlihatkan dalam Tabel 14, dan kondisi apabila AC diganti yang baru diperlihatkan dalam Tabel 15 berikut: (tarif dasar listrik PLN golongan S2 untuk gedung sebesar Rp. 900,-/ $\mathrm{kWh}$., jumlah ruangan diambil sampel pada gedung $\mathrm{B}$ ada 15 ruang)

Tabel 15. Alternatif 1 Penggantian dan Penambahan AC

\begin{tabular}{cccccc}
\hline \multirow{2}{*}{ Ruang } & $\begin{array}{c}\text { Jumlah } \\
\text { Unit }\end{array}$ & $\begin{array}{c}\text { Output Capacity } \\
(\mathrm{BTU} / \mathrm{h})\end{array}$ & $\begin{array}{c}\text { Kebutuhan } \\
\text { pengkondisi } \\
(\mathrm{BTU} / \mathrm{h})\end{array}$ & $\begin{array}{c}\text { Konsumsi } \\
\text { Listrik } \\
(\mathrm{kWh} / \text { tahun })\end{array}$ & $\begin{array}{c}\text { Pembayaran } \\
\text { Listrik PLN } \\
(\mathrm{Rp})\end{array}$ \\
\hline Kelas & 4 & $54.000 \mathrm{BTU}$ & $52.153 \mathrm{BTU}$ & $12.789,6$ & 11.510 .640 \\
Jumlah & 60 & \multirow{2}{*}{$810.000 \mathrm{BTU}$} & $782.295 \mathrm{BTU}$ & 191.844 & 172.659 .600 \\
\hline
\end{tabular}

Alternatif 1: Penggantian AC sesuai dengan kebutuhan ruangan, kondisi saat ini masih belum maksimal. Gambar 9. Menunjukkan perbandingan output AC.
Perbandingan Output AC dan Kebutuhan Pendinginan (Btu/h)

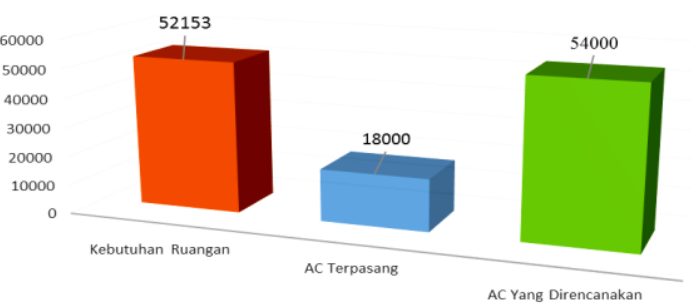

Gambar 9. Perbandingan output AC

Tabel 16. Perhitungan Ekonomis AC Yang Direncanakan

\begin{tabular}{|l|r|}
\hline B/C Ratio & 0.76 \\
\hline Net B/C Ratio & 1.12 \\
\hline IRR & $60.41 \%$ \\
\hline Payback Period & 2.39 Tahun \\
\hline BEP & $1,200,249,288$ \\
\hline NPV & $239,652,289$ \\
\hline
\end{tabular}

Dari Tabel 16. memperlihatkan perhitungan nilai ekonomis teknik dan didapatkan hasil nilai:

1. Net $\mathrm{B} / \mathrm{C}$ ratio sebesar 1,12 yang lebih besar dari 1 , artinya kegiatan penggantian AC layak untuk dilaksanakan.

2. Dari nilai IRR sebesar $60,41 \%$ yang lebih besar dari nilai MARR (nilai suku bungan tertinggi diperoleh dari BI rate yang sebesar 15\%) maka kegiatan penggantian AC cukup untuk dilaksanakan.

3. Dari periode pengembalian modal (BEP / Break Event Point) diperoleh selama 2 tahun 4 bulan. Dari keuntungan pemasangan AC baru dapat dilihat dari nilai BEP sebesar Rp. 1.200.249.288 yang terjadi pada tahun ke 3.

Alternatif 2 : Penggantian AC lama dengan AC inverter kapasitas yang sama.

Pada Alternatif 2 ini dilakukan penggantian AC hanya berdasarkan kesamaan kapasitas AC dengan konsumsi energi listrik yang lebih kecil (AC Inverter), tetapi tanpa mempertimbangkan rasa kenyamanan pengguna dalam ruangan. Hasil perhitungan ditunjukkan dalam Tabel 17.

Tabel 17. Alternatif 2 Penggantian AC Lama

\begin{tabular}{cccccc}
\hline Kondis & $\begin{array}{c}\text { Jumlah } \\
\text { Unit }\end{array}$ & $\begin{array}{c}\text { Output Capacity } \\
(\mathrm{BTU} / \mathrm{h})\end{array}$ & $\begin{array}{c}\text { Kebutuhan } \\
\text { pengkondisi } \\
(\mathrm{BTU} / \mathrm{h})\end{array}$ & $\begin{array}{c}\text { Konsumsi } \\
\text { Listrik } \\
(\mathrm{kWh} / \text { tahun })\end{array}$ & $\begin{array}{c}\text { Pembayaran } \\
\text { Listrik PLN } \\
(\mathrm{Rp})\end{array}$ \\
\hline Kelas & 2 & $20.000 \mathrm{BTU}$ & $52.153 \mathrm{BTU}$ & $4.263,2$ & 3.836 .880 \\
Jumlah & 30 & $60.000 \mathrm{BTU}$ & $782.295 \mathrm{BTU}$ & 63.948 & 57.553 .200 \\
\hline
\end{tabular}

Dari Tabel 17 memperlihatkan bahwa apabila dilakukan penggantian AC tanpa memperhatikan kebutuhan pendinginan ruangan/ kebutuhan BTU/h , maka jika ditinjau dari segi konsumsi energi listrik didapatkan hasil sebagai berikut:

a. Pada AC Lama Konsumsi Energi Listrik selama satu tahun sebesar $73.584 \mathrm{kWH}$.

Biaya rekening listrik selama satu tahun $=\mathrm{Rp}$. 66.225.600,-

b. Pada AC Baru Konsumsi Energi Listrik selama satu tahun sebesar $63.948 \mathrm{kWH}$. 
Biaya rekening listrik selama satu tahun $=\mathrm{Rp}$. 57.553.200,-

\section{KESIMPULAN}

1. Dari audit energi awal didapatkan nilai IKE masing-masing gedung (gedung $\mathrm{A}$, gedung $\mathrm{B}$, dan gedung C) pada tahun 2016 sebesar 77,82 $\mathrm{KWH} / \mathrm{m}^{2} /$ tahun, $40,25 \mathrm{KWH} / \mathrm{m}^{2} /$ tahun , 37,15 $\mathrm{KWH} / \mathrm{m}^{2} /$ tahun, sedangkan pada tahun 2017 nilai IKE pada gedung A adalah $87,49 \mathrm{KWH} / \mathrm{m}^{2} /$ tahun, gedung B $50,82 \mathrm{KWH} / \mathrm{m}^{2} /$ tahun dan gedung $\mathrm{C}$ $35,65 \mathrm{KWH} / \mathrm{m}^{2} /$ tahun. Nilai tersebut menunjukkan bahwa nilai IKE masih tergolong dalam kategori efisien. Dengan demikian audit energi rinci tidak perlu dilakukan. Alternatif 1 penggantian AC dilakukan karena kebutuhan ruangan masih belum terpenuhi sehingga tingkat kenyamanan pengguna tidak terpenuhi, sedangkan alternatif ke 2 penggantian AC dilakukan hanya dengan memperkecil daya yang dipergunakan / menggunakan AC hemat energi.

2. Dari segi pemakaian energi listrik per komponen didapatkan bahwa sektor AC (Air Conditioner) pada gedung A sebesar $67,90 \%$, pada gedung B sebesar $139,15 \%$, dan gedung C $128,95 \%$. Nilai tersebut melebihi rata-rata persentase penggunaan energi pada bangunan gedung sebesar $60 \%$.

3. Peluang hemat energi masih dapat dilakukan dengan mengadakan penggantian AC yang lama dengan AC yang baru yaitu dengan penyesuaian kebutuhan pendinginan ruangan dan diperoleh penghematan energi listrik sebesar $13 \%$.

\section{Referensi}

[1] BPS .Data Outlook Energi Indonesia .2013, Nopember 15, 2017. http://www.bps.go.id/brs/view/id/1143.

[2] Direktorat Jenderal Listrik dan Pemanfaatan Energi, Penyusunan Indikator Efisiensi Energi dan Benchmarking, Desember 2010.

[3] Peraturan Menteri ESDM No. 28 tahun 2016.http://www.listrik.org/pln/tarif-dasar-listrik-pln/ diakses pada 10 Oktober 2017

[4] Richard Blocher,Dipl.Phys "Dasar Elektronika”, Penerbit Andi, Yogyakarta,2003.

[5] Hasan Shalahuddin, "Pelaksanaan Efisiensi Energi di Bangunan Gedung”, www.nulisbuku.com. Diakses pada 10 Oktober 2017.

[6] SNI 6196:2011. "Prosedur Audit Energi pada Bangunan Gedung”. Jakarta: DirektoratJenderalKetenagalistrikan, KementrianEnergi dan SumberDaya Mineral. Maret 2010.

[7] Berchmans Hanny, Saifudin Suaib, Imas Agustina, Richard Panjaitan, Winne, "Panduan Penghematan Energi di Gedung Pemerintah”. 2014. www.iced.or.id. Diakses 10 Oktober 2017.

[8] Departemen Pendidikan Nasional Republik Indonesia, Pedoman Pelaksanaan Konservasi Energi dan Pengawasan di Lingkungan Departemen Pendidikan Nasional, Jakarta. 2006.

[9] Sugiyono, "Statistika Untuk Penelitian", CW Aifabeia, Bandung.2012

[10] Halim Abdurrahmim, Pasek, Darmawan Ari dan Sulaiman, Audit Energi, Energi Conservation Efficiency And Cost Saving Course, Bandung. TA.2002.

[11] Wahyudi Biantoro Agung, Dadang S.Permana, "Analisis Audit Energi Untuk Pencapaian Efisiensi Energi Di Gedung AB, Kabupaten Tangerang,Banten". Jurnal Teknik Mesin (JTM): Vol.06, No.2, Maret 2017.

[12] Hendra R.H. 2007. Audit Energi Pada Bangunan Gedung Rumah Sakit Dr. Karyadi, Semarang. Semarang

[13] Roosita, D. 2015. Audit Energi Listrik Pada AC dan Pencahayaan Dalam Upaya Efisiensi Energi di RS Islam Surakarta. Yogyakarta. Electronic Theses \& Dissertations (ETD) Gadjah Mada University, Universitas Gadjah Mada, 2015, Yogyakarta.

[14] Nugraha,W.S. 2015. Audit Energi Listrik dan Identifikasi Peluang Konservasi Energi Listrik Pada Sistem Pencahayaan dan Pendingin Ruangan di RS Akademik Universitas Gadjah Mada Yogyakarta. Yogyakarta. Electronic Theses \& Dissertations (ETD) Gadjah Mada University, Universitas Gadjah Mada, 2015, Yogyakarta.

[15] Pasisarha DS. Evaluasi IKE Listrik Melalui Audit Awal Energi Listrik di Kampus Polines. Jurnal Teknik Elektro Terapan (JTET) ISSN: 2252-4908 Vol. 1 No. 1 April 2012: 1-7.

\section{Biography}

Paskalia Kartini, lahir di Pontianak pada tanggal 21 April 1973. Menyelesaikan pendidikan S-1 Teknik Elektro di Universitas Tanjungpura Pontianak Tahun 1998 dan S-2 Teknik Elektro di Universitas Tanjungpura Pontianak Tahun 2017. Sejak tahun 2007 sampai dengan sekarang bekerja sebagai Staf Pengajar di STMIK Widya Dharma Pontianak. 